\title{
VYUŽITÍ MAGNETICKÉ SUSCEPTIBILITY A DALŠÍCH PROSTŘEDKŮ PRO STUDIUM POVODŇOVÝCH SEDIMENTU゚ V ANTROPOGENNĚ OVLIVNĚNÉ NIVĚ ŘEKY OLŠE
}

\author{
The use of magnetic susceptibility and other proxies for investigation of overbank \\ sediments in the anthropogenic influenced floodplain of the Olše River, Czech Republic
}

\author{
Monika Chudaničová \\ Katedra fyzické geografie a geoekologie PřF OU, Chittusiho 10, 71000 Ostrava; e-mail: monika.chudanicova@osu.cz
}

(15-44 Karviná)

Key words: fluvial sediments, magnetic susceptibility, sedimentary record, the Olše River, anthropogenic impact

\begin{abstract}
Magnetic susceptibility (MS) is very useful proxy for determination of anthropogenic pollution in environment, also in fluvial sediments. In this paper MS was used as the lead method for the anthropogenic impact and floodplain development determination. Sedimentary records of total six cores were examined in the Olše River floodplain. Besides MS measurements other laboratory analyses (loss on ignition, grain-size analyses) were done. This set of laboratory analyses was supported by study of the old maps, historical aerial photos and archive river management and flood records. The stream path in the study area was significantly influences by 1930s channelization. The study area also lies in very industrial region where the coal extraction, attached steel production and fly ashes concentration culminated in 1980s and has been decreasing from that time. The basic assumption for sedimentary record interpretation was that MS peak determines the 1980s.

According to MS measurement upper fines of all investigated cores are very young because they are completely magnetically enhanced. Most of them were evidently deposited on the former gravel streambed after the 1930s channelization. Also high mass specific MS values were reported $\left(14.72-382.09 \times 10^{-8} \mathrm{~m}^{3} / \mathrm{kg}\right)$.
\end{abstract}

Úvod

Ř́ční nivy se svými sedimenty jsou cenným zdrojem informací o historii řeky a prostředí, ve kterém řeka teče. Každá změna říčního vzoru má významný vliv na sedimentaci v nivě (Brown 1997). Hlavním úkolem pro studium sedimentárního záznamu je jeho interpretace a stanovení stratigrafie. Recentní sedimenty ale nejsou datovatelné pomocí metody ${ }^{14} \mathrm{C}$ díky vysokým fluktuacím tohoto izotopu v prostředí v posledních letech, proto se využívají jiné metody (Matys Grygar et al. 2011), mezi nimi i magnetická susceptibilita.

Magnetická susceptibilita je součástí environmentálního magnetismu a charakterizuje rozdílné odezvy různých materiálů na magnetické pole, jinými slovy to, jak moc je materiál magnetizovatelný. Čím více ferromagnetických nebo ferrimagnetických částic materiál obsahuje, tím vyšší je jeho magnetická susceptibilita. Ferromagnetické látky jako čisté železo nejsou přirozenou součástí prostředí, ale mohou se do něj dostávat ve formě odpadů, oděrů apod. Naproti tomu ferrimagnetické ćástice se nachází ve všech vyvřelých horninách, většině sedimentárních hornin a takřkka ve všech půdách. Jedná se o minerály obsahující železo, napríklad magnetit (Dearing 1999). Ferrimagnetické částice mohou vznikat rovněž antropogenně. Vznikají z pyritu při vysokoteplotním spalování uhlí a do prostředí se dostávají depozicí industriálních polétavých prachů. Dalšími antropogenními zdroji magnetických částic jsou odpadní vody a silniční doprava. $Z$ těchto důvodů může být magnetická susceptibilita použita jako vhodný prostředek pro určení antropogenního znečištění prostředí, i říční nivy (Petrovský et al. 2000, Li et al. 2011, Kapička et al. 2001).
Hodnoty magnetické susceptibility jsou tedy citlivé na antropogenní znečištění a aktivity člověka $\mathrm{v}$ povodí. Při interpretaci sedimentárního záznamu v této studii se pracovalo s předpokladem, že vrchol na křivce magnetické susceptibility zřejmě odpovídá 80 . letům 20 . století, tedy období kulminace těžkého průmyslu v České republice.

\section{Charakteristika zájmové oblasti}

Olše pramení v Polsku pobliž obce Istebna, po $16 \mathrm{~km}$ protíná státní hranici s Českou republikou a teče severozápadním směrem. Celková délka toku je $97,8 \mathrm{~km}$ a plocha povodí je 1 120,67 km² (Povodí Odry 1954).

Horninové podloží povodí je tvořeno neogenními pískovci, jílovci a slepenci, které jsou hlavními zdroji rríčního aluvia. Doplňkově se objevují také křemeny, rohovce, lydity, těšínity a valouny hornin nordického původu (Macoun et al. 1965).

Zájmová oblast se nachází na východě České republiky mezi obcemi Karviná a Doubrava, v katastrálním území Staré Město u Karviné. Jedná se o dolní tok řeky Olše v délce cca $2 \mathrm{~km}$ a přilehlou nivu (ř́íní $\mathrm{km} \mathrm{17,000-}$ $19,000)$. Ještě na začátku 20 . století zde řeka měla 100 až $300 \mathrm{~m}$ široké řečiště $\mathrm{s}$ rozsáhlými štěrkovými lavicemi. V 30. letech 20. století byl přirozený tok nahrazen $28 \mathrm{~m}$ širokým napřímeným umělým korytem $s$ vegetačním opevněním břehů (Brosch - Maniček 1978). V roce 1962 byly postaveny protipovodňové valy na obou stranách toku. Vegetační opevnění pak bylo nahrazeno kamenným v 60. letech 20. století (obr. 1) (Útvar hlavního architekta okresu Karviná 1966).

Od dob objevu uhlí na konci 18. století se region, ve kterém se zájmová oblast nachází, stal nejprůmyslověj- 


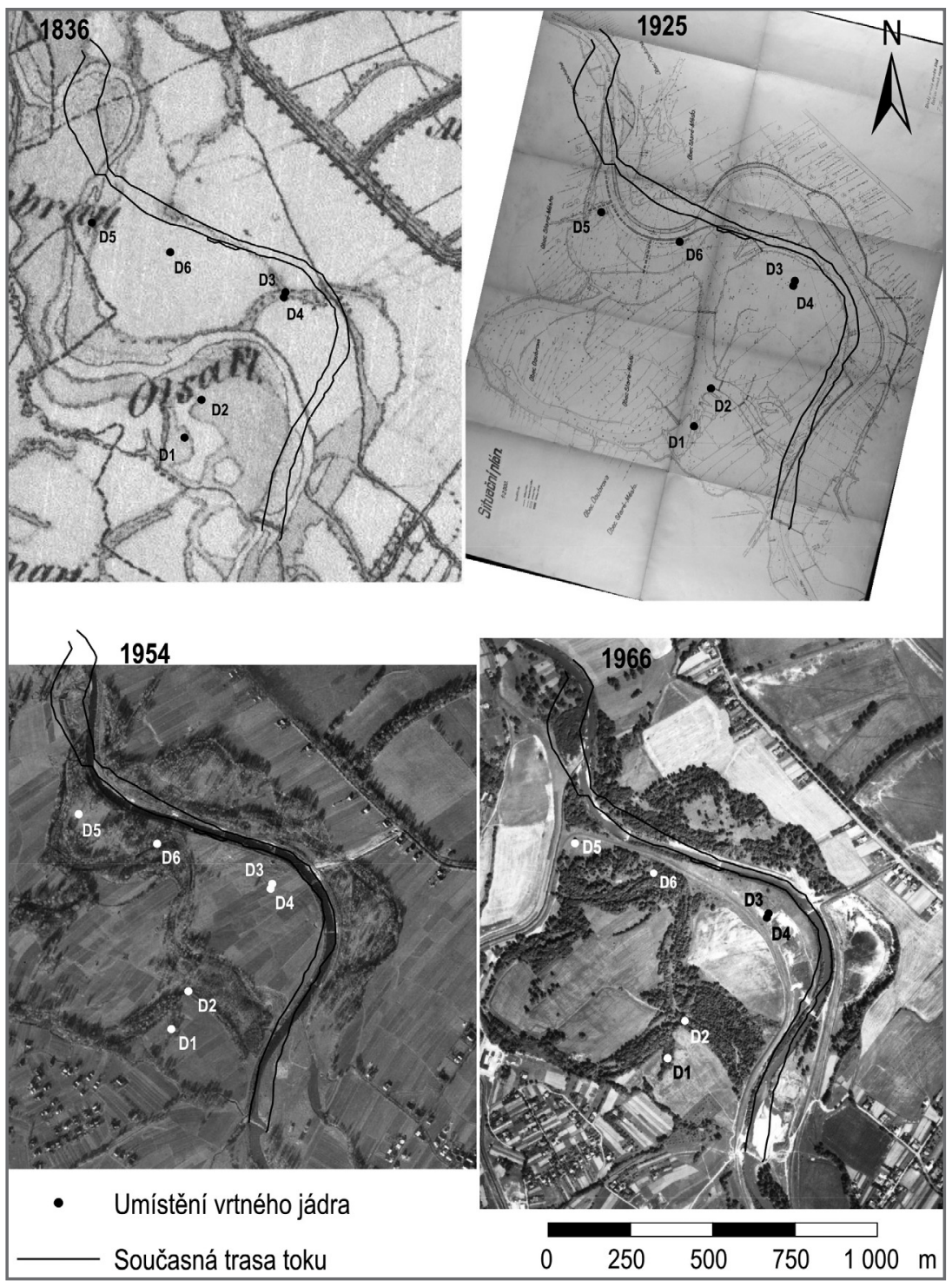

Obr. 1: Lokalizace vrtů D1 až D6 a vývoj zájmového území v čase.

Fig. 1: Cores D1 to D6 location and evolution of the study area over time.

Malvern. Před měřením byly všechny vzorky suspendovány ve vodě a homogenizovány ultrazvukem po dobu 1 minuty. Zrnitostní složení štěrků a štěrkopísků bylo stanoveno mokrou sítovou granulometrií.

Obsah organického uhlíku byl zjištěn pomocí ztráty váhy žíháním, tak jak ji popsal Dean (1974). Vysušené vzorky byly zváženy a zahřáty na teplotu $550{ }^{\circ} \mathrm{C}$, poté byly znovu zváženy. Rozdíl vah pak odpovídá organickému uhlíku obsaženému ve vzorcích.

\section{Výsledky Vrty D1 a D2}

Vrty D1 a D2 pocházejí ze dvou sousedních starých ramen z prostoru za protipovodňovými valy (obr. 1). Pouze tenká vrstva jemnozrnných sedimentů se nacházela na povrchu obou vrtů $(40 \mathrm{~cm} \mathrm{u} \mathrm{D1}$, resp. $24,5 \mathrm{~cm} \mathrm{u} \mathrm{D2).} \mathrm{Pod} \mathrm{vrstvou}$ jemných sedimentů ležely štěrky. Tato stará ramena byla opuštěna ve 30. letech 20. století po napřímení toku. Štěrky tedy tvoří korytovou facii uloženou do 30. let a svrchní jemnozrnné sedimenty jsou výsledkem povodňové depozice nebo depozice ze sloupce stojaté vody $\mathrm{v}$ rameni po odstavení. S největší pravděpodobností žádná z povodní nedosáhla na tato místa po stavbě protipovodňových valů $\mathrm{v}$ roce 1962. To by znamenalo, že $40 \mathrm{~cm}$, resp. $24,5 \mathrm{~cm}$ vrstva jemnozrnných sedimentů je výsledkem depozice

ším v celé České republice. Těžba uhlí, přidružený hutní průmysl a koncentrace polétavého prachu kulminovaly v 80. letech 20 . století a od té doby klesají. V současnosti se zde nachází trri aktivní černouhelné doly a dva hutní podniky na výrobu železa.

\section{Metody}

Pomocí vrtné soupravy Eijkelkamp s průměrem $6,3 \mathrm{~cm}$ bylo odebráno 6 vrtných jader (D1 až D6) z prostoru nivy. Jemné povodňové sedimenty byly rozděleny na jednotlivé vzorky po $2,5 \mathrm{~cm}$. U štěrků a štěrkopísků byl odebrán 1 vzorek z každé homogenní vrstvy.

Na všech jemnozrnných vzorcích bylo vykonáno měření nízkofrekvenční objemové magnetické susceptibility ( $)$ a hmotnostně specifické magnetické susceptibility $(\chi)$. Měření probíhalo na přístroji MS2B Bartington v plastových kelímcích o objemu $10 \mathrm{~cm}^{3}$. Všechny vzorky byly před měřením vysušeny.

Zrnitostní analýzy jemnozrnných vzorků byly vykonány za použití laserového přístroje Mastersizer 2000 firmy v letech cca 1930-1962. Tomu odpovídá průběh $\chi$ křivky, která nemá maximum, a její hodnoty narůstají směrem k povrchu (obr. 2, 3).

\section{Vrty D3 a D4}

Vrty D3 a D4 byly pořízeny v prostoru mezi protipovodňovými valy (obr. 1). Umístění vrtu D3 bylo na dně starého ramene. Ačkoli toto vypadalo jako ostatní stará ramena v oblasti, na snímku z roku 1954 je v těchto místech viditelná obdělávaná zemědělská půda (obr. 1). Mohlo by se tedy jednat o povodňové koryto vzniklé po roce 1954. Orniční vrstva nebyla ve vrtu přítomná, a to bud’ proto, že byla odstraněna erozí, změněna půdotvornými procesy, anebo odstraněna skrývkou. Svrchní jemnozrnné sedimenty byly $80 \mathrm{~cm}$ mocné a složené $\mathrm{z}$ mnoha tenkých vrstviček, které pak byly na základě zrnitostní analýzy sloučeny do 6 vrstev. Hranice mezi vrstvami se většinou shodují s vrcholy na křivce organického obsahu (obr. 4). To může být interpretováno v tom smyslu, že probíhající pedogeneze na povrchu nivy byla přerušena dodávkou 


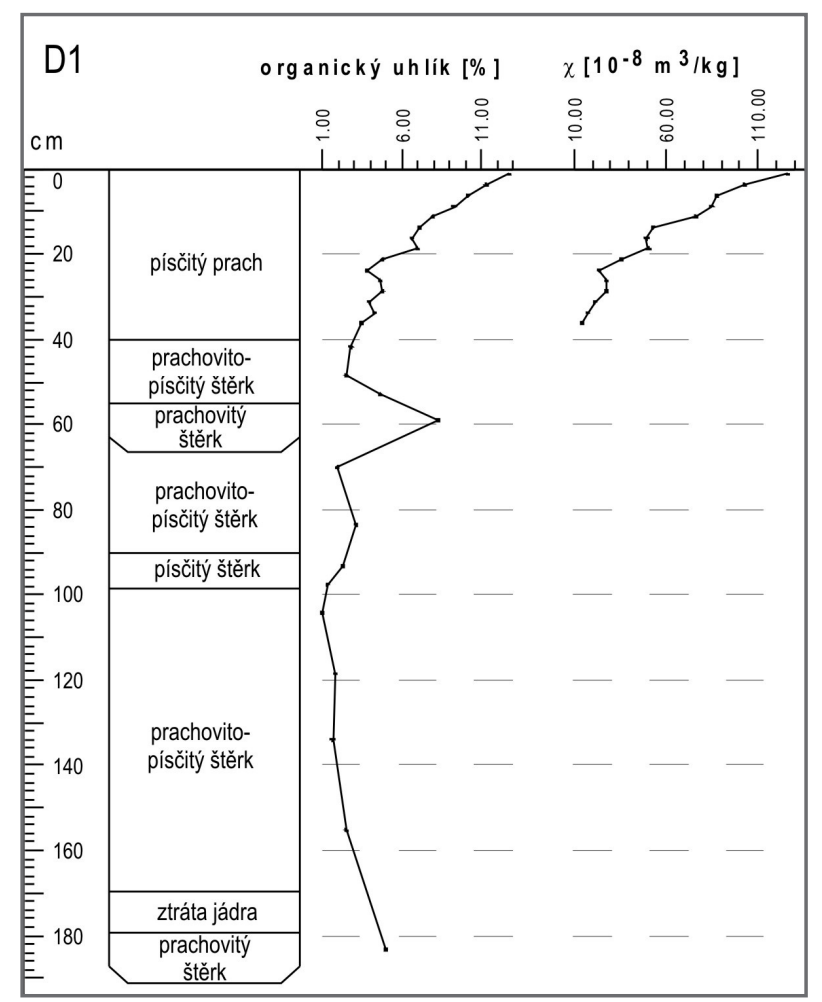

Obr. 2: Výsledky měřených charakteristik vrtu D1 ( $\chi$ - hmotnostně specifická magnetická susceptibilita).

Fig. 2: Measured values of the core D1 ( $\chi$ - mass specific magnetic susceptibility).

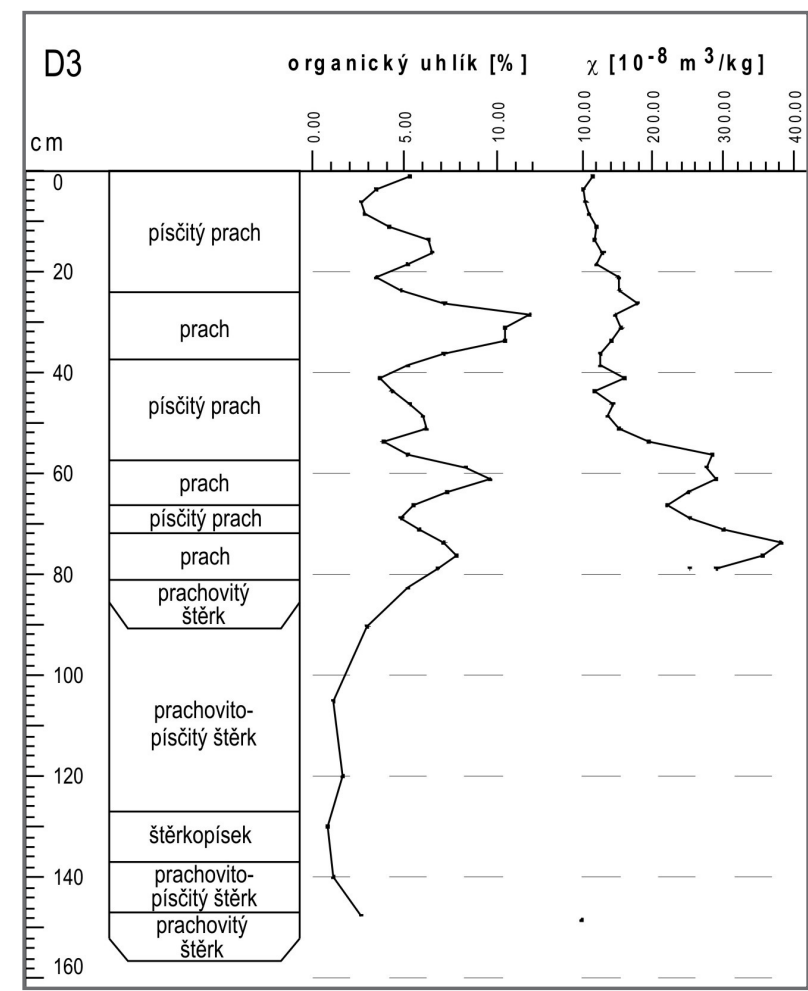

Obr. 4: Výsledky měřených charakteristik vrtu D3 ( $\chi$ - hmotnostně specifická magnetická susceptibilita).

Fig. 4: Measured values of the core D3 ( $\chi$ - mass specific magnetic susceptibility).

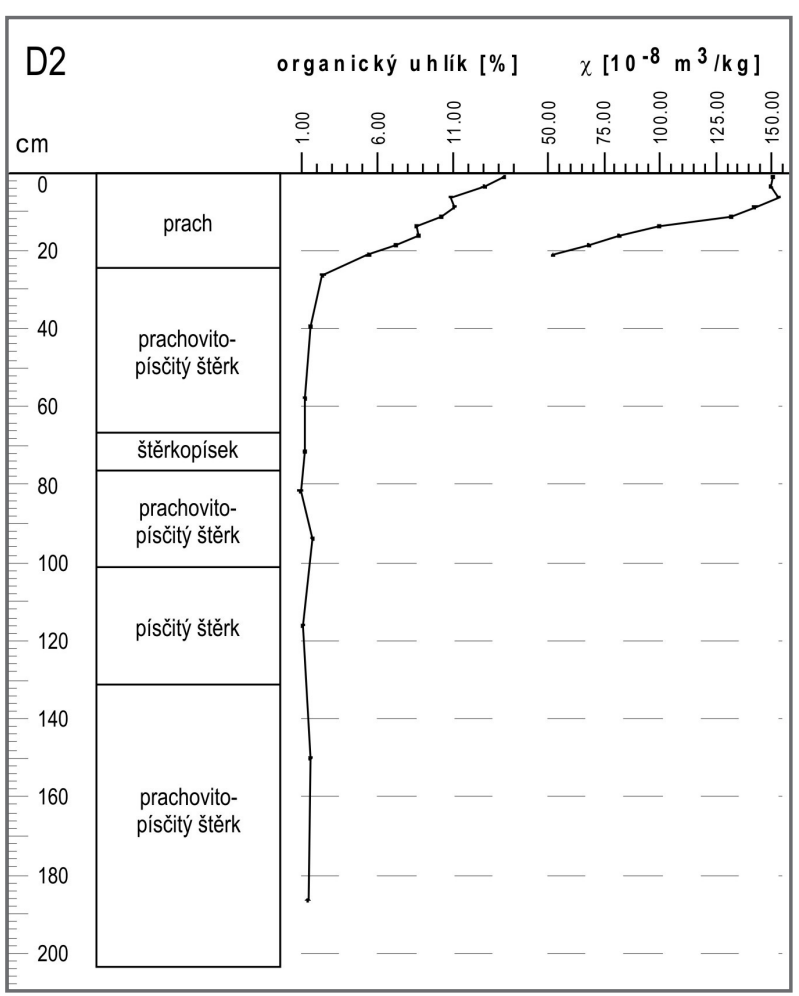

Obr. 3: Výsledky měřených charakteristik vrtu D2 ( - hmotnostně specifická magnetická susceptibilita).

Fig. 3: Measured values of the core D2 ( $\chi$ - mass specific magnetic susceptibility).

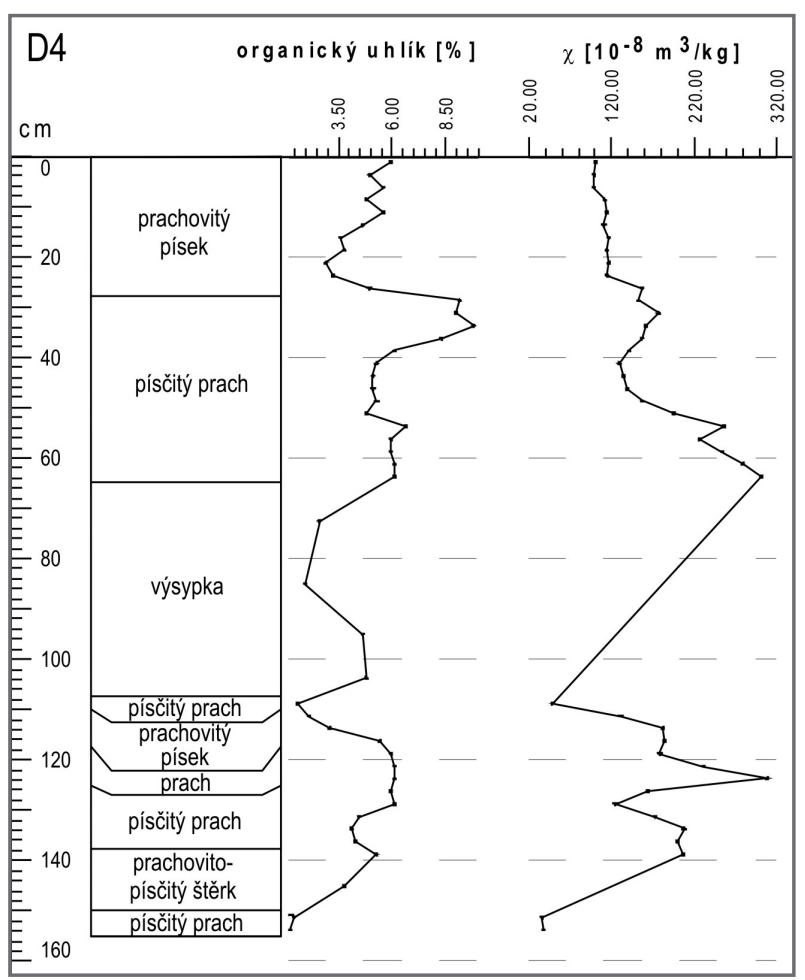

Obr. 5: Výsledky měřených charakteristik vrtu D4 ( $\chi$ - hmotnostně specifická magnetická susceptibilita).

Fig. 5: Measured values of the core D4 ( $\chi$ - mass specific magnetic susceptibility). 


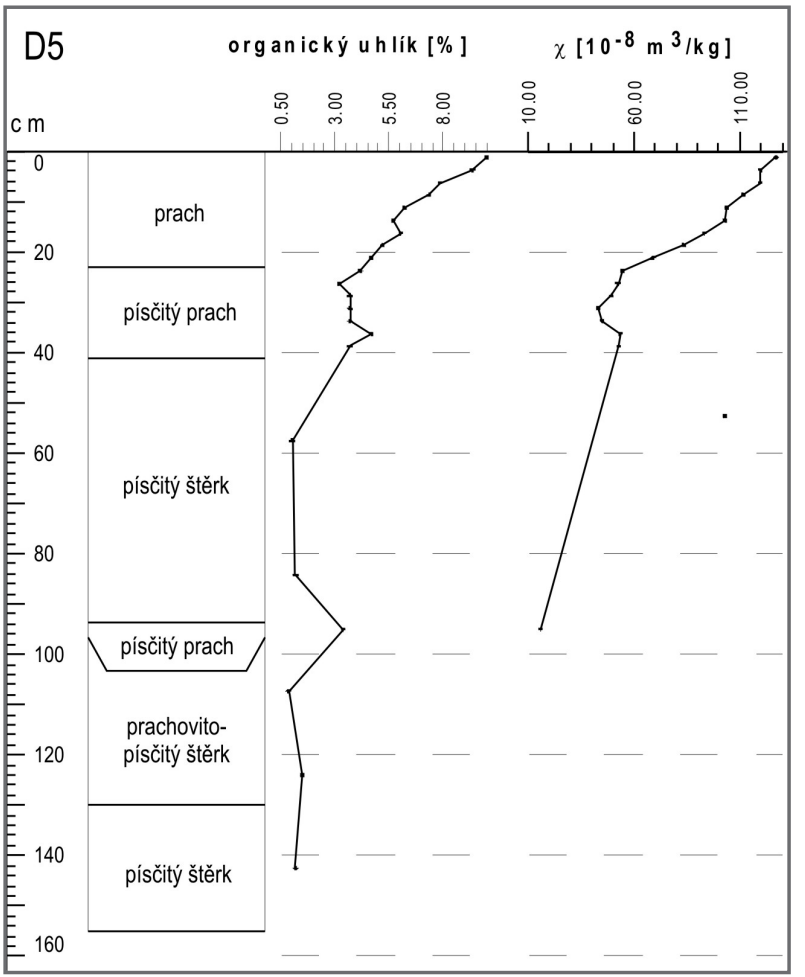

Obr. 6: Výsledky měřených charakteristik vrtu D5 ( $\chi$ - hmotnostně specifická magnetická susceptibilita).

Fig. 6: Measured values of the core D5 ( $\chi$ - mass specific magnetic susceptibility).

čerstvých sedimentů $\mathrm{z}$ inundace při povodni. Podle záznamů, které jsou k dispozici, je známo, že na toto místo dosáhly povodně v letech 2010 a 1997. Podle hodnot $\chi$ je zřejmé, že se jedná o mladé sedimenty, protože jsou v celé své mocnosti magneticky ovlivněny. Pokud bychom vycházeli z předpokladu, že vrchol křivky určuje 80. léta 20. století, pak by $75 \mathrm{~cm}$ sedimentů bylo výsledkem ukládání během cca 30 let. To, že jsou sedimenty velmi mladé, dokládá i nález fóliového plastu v hloubkách 17,5-22,5 a 72,5 cm.

Vrt D4 byl pořízen poblíž vrtu D3, ovšem mimo staré rameno. Vrstva svrchních jemnozrnných sedimentů $(60 \mathrm{~cm})$ obsahovala více písčité frakce než u vrtu D3. Pod touto vrstvou se nacházely štěrky do hloubky $107,5 \mathrm{~cm}$. Po bližším prozkoumání bylo zřejmé, že se nejedná o korytovou facii, ale o úložiště odpadu, který obsahoval kusy betonu, cihel a ostrohranných stavebních břidlic. Pod touto vrstvou se nacházela znovu vrstva jemnozrnných sedimentů a v největší hloubce vrtu pak štěrková korytová facie. Vrstva odpadu musela vzniknout pravděpodobně až po roce 1954 vzhledem k obdělávané zemědělské půdě $\mathrm{v}$ těchto místech. Podle $\chi$ křivky by mohla být mladší než 30 let, protože $\chi$ maximum leží až pod ní v hloubce $125 \mathrm{~cm}$ (obr. 5). V hloubce 10 a $60 \mathrm{~cm}$ se našly kusy náplasti.

Křivky organického obsahu obou vrtů jsou velmi podobné, největší shoda je v lokálním maximu, které leží v hloubce $30 \mathrm{~cm}$ (D3), resp. $35 \mathrm{~cm}$ (D4).

\section{D5 a D6}

Vrty D5 a D6 jsou oba z prostoru za protipovodňovými valy, D6 je ze starého ramene, D5 ze sousedního prostoru nivy (viz obr. 1). Tato místa nebyla ovlivněna

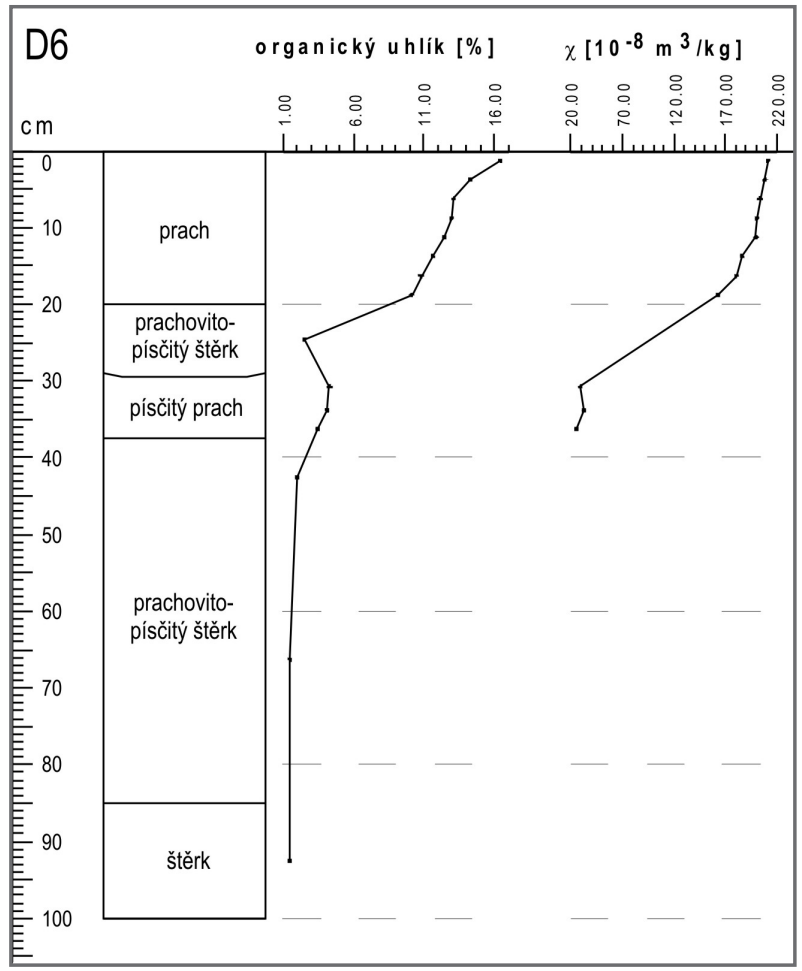

Obr. 7: Výsledky měřených charakteristik vrtu D6 ( $\chi$ - hmotnostně specifická magnetická susceptibilita).

Fig. 7: Measured values of the core D6 ( $\chi$ - mass specific magnetic susceptibility).

žádnou povodní po roce 1962, pouze povodní 1997, která dosahovala značných rozměrů a dostala se zde skrz valy.

Křivky x jsou podobné jako u vrtů D1 a D2 (obr. 6, 7), což je trochu neočekávané, protože vrty D1 a D2 nebyly ovlivněny povodní v roce 1997. Nepřítomnost vrcholu na křivce $\chi$ je zřejmě způsobena diskontinuitou dodávky sedimentů. Nižší polohy jemnozrnných sedimentů s nízkými hodnotami $\chi$ jsou pravděpodobně výsledkem sedimentace do roku 1962 a svrchní polohy výsledkem povodně v roce 1997.

Štěrková korytová facie vrtu D6 v hloubce 20-29 cm byla pravděpodobně vytvořena povodní v roce 1997, kdy se koryto mohlo stát znovu aktivním a mohlo transportovat větší dnové splaveniny.

\section{Diskuze \\ Stratigrafie založená na industriálním znečištění}

Jak už bylo řečeno $v$ úvodu, magnetická susceptibilita je velmi citlivá na industriální znečištění - polétavý prach ze spalování uhlí a produkce železa a cementu, odpadní vody a silniční dopravu. Díky tomu je industriální éra zachycena $\mathrm{v}$ magneticky ovlivněných sedimentech. Množství industriálního znečištění také zřejmě ovlivňuje hodnoty MS. Li et al. (2011) měřili sedimenty řeky Yangtze v letech 2004-2010 a zjistili signifikantní korelaci mezi narůstajícími hodnotami MS a narůstajícím množstvím spalovaného uhlí. Plater et al. (1998) ve Velké Británii zjistili vrchol MS, který odpovídá 50. letům 20. století, což souhlasí s kulminací těžkého průmyslu v západní Evropě. V zájmové oblasti, resp. v celé České republice, kulminovaly těžba uhlí, přidružený hutní průmysl a koncentrace 
polétavého prachu v ovzduší v 80 . letech 20 . století a od té doby postupně klesají. Vrchol MS v 80. letech a následný pokles zaznamenali někteř́i čeští autoři pomocí ${ }^{137} \mathrm{Cs}$ datování (Hradecký, Pánek - dosud nepublikovaná data, Bábek et al. 2011).

\section{Hodnoty MS a původ znečištění}

Podle výsledků několika českých autorů (Hradecký, Pánek - dosud nepublikovaná data, Kadlec et al. 2009) a podle naměřených hodnot na řece Lučině (dosud nepublikovaná data) se $\chi$ starších sedimentů v hloubkách stává víceméně konstantní a osciluje kolem hodnoty $10 \times 10^{-8} \mathrm{~m}^{3} / \mathrm{kg}$. Tuto hodnotu bychom tedy mohli považovat za přirozené pozadí regionu způsobené přirozenými faktory. Hodnoty $\chi$ vrtů D1 až D6 se pohybují v rozmezí $14,72-382,09 \times 10^{-8} \mathrm{~m}^{3} / \mathrm{kg}$, což ukazuje na vysoké magnetické ovlivnění sedimentů. Výsledky z méně industriálních regionů České republiky jsou např. $5-45 \times 10^{-8} \mathrm{~m}^{3} / \mathrm{kg}$ (Kadlec et al. 2009), 10-26 $\times 10^{-8} \mathrm{~m}^{3} / \mathrm{kg}$ (Matys Grygar et al. 2011), $1-20 \times 10^{-8} \mathrm{~m}^{3} / \mathrm{kg}$ (Pánek et al. in press), $1,5-40 \times 10^{-8} \mathrm{~m}^{3} / \mathrm{kg}$ (Nehyba et al. 2011). Podobně vysoké hodnoty jako na Olši naměřili Li et al. (2011) v Číně v sedimentech řeky Yangtze: $35-212 \times 10^{-8} \mathrm{~m}^{3} / \mathrm{kg}$. Li et al. (2011) považovali za hlavní zdroj magnetických částic industriální polétavý prach. Vzhledem k tomu, že zájmová oblast se nachází v jednom z evropských regionů s nejvyšším znečištěním ovzduší, byl polétavý prach také nejprve považován za hlavní faktor magnetického obohacení sedimentů. Ale později odebrané vzorky $\mathrm{z}$ aluvia řeky Lučiny, protékající stejným regionem, měly $\chi$ pouze do $100 \times 10^{-8} \mathrm{~m}^{3} / \mathrm{kg}$. Vyšší hodnoty $\chi \mathrm{v}$ zájmovém území na Olši jsou zřejmě způsobeny odpadními vodami z Třineckých železáren, kterými Olše protéká v délce $6 \mathrm{~km}$.

\section{Mocnost magneticky ovlivněných sedimentů a míra sedimentace}

Svrchní jemnozrnné sedimenty všech jader jsou magneticky ovlivněny prakticky v celé své mocnosti, což znamená, že jsou velmi mladé. Jemnozrnné sedimenty vrtů D1, D2 a D6 byly s největší pravděpodobností uloženy po odstavení ramen v 30. letech 20. století, jemnozrnné sedimenty ostatních vrtů jsou zřejmě stejně staré a pravděpodobně byly uloženy na dřívějším širokém štěrkovém řečišti po např́imení toku a změně říčního vzoru.

Výstavba protipovodňových valů v roce 1962 ovlivnila sedimentační míry, což je patrné z rozdílné mocnosti povodňových sedimentů $\mathrm{v}$ prostoru před a za protipovodňovými valy. Mocnost povodňových sedimentů před valem je cca $100 \mathrm{~cm}$, zatímco mocnost sedimentů za valem dosahuje pouze $\mathrm{k} 40 \mathrm{~cm}$.

\section{Závěr}

Lidské zásahy v zájmové oblasti ovlivnily vývoj nivy a jsou zjevné jak v historickém, tak i sedimentárním záznamu. Souvislá vodohospodářská úprava řeky v 30. letech 20. století způsobila nejenom přímou změnu trasy toku a říčního vzoru, ale také vyvolala povodňovou sedimentaci jemnozrnného materiálu na dřivějším rozsáhlém řečišti $\mathrm{s}$ velkými štěrkovými lavicemi. Stavba protipovodňových valů v roce 1962 pak ovlivnila míry sedimentace, povodňové jemnozrnné sedimenty se začaly kumulovat v prostoru mezi valy a mimo tento prostor se zřejmě dostala pouze povodeň v roce 1997.

Magnetická susceptibilita má velký potenciál využití jako stratigrafický prostředek pro recentní sedimenty. Nezbytné ale je identifikovat zdroj ferrimagnetických a ferromagnetických částic a dobu kulminace zdroje. $\mathrm{V}$ prrípadě více zdrojů magnetických částic je situace složitější, pokud nemají stejnou dobu kulminace. Další studie jsou nezbytné pro hlubší poznání možností této metody.

Ačkoli většina prací hovoří o polétavém prachu jako o hlavním zdroji magnetického ovlivnění sedimentů, výsledky z Olše a Lučiny ukazují, že příspěvek polétavého prachu k hodnotám $\chi$ je limitován a významnou roli hrají další faktory, zřejmě odpadní vody z hutního průmyslu.

\section{Poděkování}

Tento př́spěvek vznikl za podpory projektu SGS15/PřF/2013

- Geomorfologie a geoekologie horských a podhorských regionu․ 


\section{Literatura}

Brown, A. G. (1997): Alluvial Geoarchaeology: Floodplain archeology and environmental change. - Cambridge University Press, Cambridge, $377 \mathrm{pp}$.

Bábek, O. - Faměra, M. - Hilscherová, K. - Kalvoda, J. - Dobrovolný, P. - Sedláček, J. - Machát, J. - Holoubek, I. (2011): Geochemical traces of flood layers in the fluvial sedimentary archive; implications for contamination history analyses. - Catena, $87,281-290$.

Brosch, O. - Maníček, J. (1978): Studie ovlivnění odtokových poměrů v povodí Olše výhledovou činností Dolu ČSM ve Stonavě. - Ostrava.

Dean, W. E. (1974): Determination of carbonate and organic matter in calcareous sediments and sedimentary rocks by loss on ignition: comparison with other methods. - Journal of Sedimentary Petrology, 44, 242-248.

Dearing, J. (1999): Environmental Magnetic Susceptibility: Using the Bartington MS2 System - Bartington Instruments, Oxford.

Kadlec, J. - Grygar, T. - Světlík, I. - Ettler, V. - Mihaljevič, M. - Diehl, J. F. - Beske-Diehl, S. - Svitavská-Svobodová, H. (2009): Morava River floodplain development during the last millennium, Strážnické Pomoraví, Czech Republic. - The Holocene, 19, 499-509.

Kapička, A. - Jordanova, N. - Petrovský, E. - Ustjak, S. (2001): Effect of different soil conditions on magnetic parameters of power-plant fly ashes. - Journal of Applied Geophysics, 48, 93-102.

Li, F. - Li, G. - Ji, J. (2011): Increasing magnetic susceptibility of the suspended particles in Yangtze River and possible contribution of fly ash. - Catena, 87, 141-146.

Macoun, J. - Šibrava, V. - Tyráček, J. (1965): Kvartér Ostravska a Moravské brány. - Nakladatelství Československé akademie věd, Praha, 420 pp.

Matys Grygar, T. M. - Nováková, T. - Mihaljevič, M. - Strnad, L. - Světlík, I. - Lisá, L. - Brázdil, R. - Máčka, Z. - Stachoň, Z. Svitavská-Svobodová, H. - Wray, D. S. (2011): Surprisingly small increase of the sedimentation rate in the floodplain of Morava River in the Strážnice area, Czech Republic, in the last 1300 years. - Catena, 86, 192-207.

Nehyba, S. - Nývlt, D. - Schkade, U. - Kirchner, G. - Franců, E. (2011): Depositional rates and dating techniques of modern deposits in the Brno reservoir (Czech Republic) during the last 70 years. - Journal of Paleolimnology, 45, 41-55.

Pánek, T. - Smolková, V. - Hradecký, J. - Sedláček, J. - Zernitskaya, V. - Kadlec, J. - Pazdur, A. - Řehánek, T. (in press): Late-Holocene evolution of a floodplain impounded by the Smrdutá landslide, Carpathian Mountains (Czech Republic). - The Holocene.

Petrovský, E. - Kapička, A. - Jordanova, N. - Knab, M. - Hoffmann, V. (2000): Low-field magnetic susceptibility: a proxy method of estimating increased pollution of different environmental systems. - Environmental Geology, 39, 312-318.

Plater, A. J. - Ridgway, J. - Appleby, P. G. - Berry, A. - Wright, M. R. (1998): Historical Contaminant Fluxes in the Tees Estuary, UK: Geochemical, Magnetic and Radionuclide Evidence. - Marine Pollution Bulletin, 37, 343-360.

Povodí Odry (1954): Státní vodohospodářský plán republiky Československé: Hlavní povodí Odry, dílčí SVP XVI Olše. - Brno.

Útvar hlavního architekta okresu Karviná (1966): Kladné stanovisko k věci: Ochranná hráz řeky Olše v úseku Dětmarovice Staré Město. 